\title{
An Exploration into Students' Perceptions towards the Challenges of Learning Reading Skill Using Communicative Language Teaching Approach: Focus on Wolaita Sodo Preparatory School
}

\author{
Tesfaye Buche Bosha, Desalegn Youpo Ukute \\ Faculty of Social Science and Humanities, Department of English Language and Literature, Wolaita Sodo University, Sodo, Ethiopia
}

Email address:

tesfayebuche@gmail.com (T. B. Bosha),youngyoupo19@gmail.com (D. Y. Ukute)

To cite this article:

Tesfaye Buche Bosha, Desalegn Youpo Ukute. An Exploration into Students' Perceptions towards the Challenges of Learning Reading Skill Using Communicative Language Teaching Approach: Focus on Wolaita Sodo Preparatory School. International Journal of Psychological and Brain Sciences. Vol. 4, No. 3, 2019, pp. 29-35. doi: 10.11648/j.ijpbs.20190403.11

Received: May 2, 2019; Accepted: June 5, 2019; Published: July 4, 2019

\begin{abstract}
The main purpose of this study is to explore students' perceptions towards the challenges of learning reading skill using communicative language teaching approach: focus on Wolaita Sodo Preparatory School. Descriptive research design was employed. The data were collected through classroom observations and questionnaires. Students were selected the sample using Slovene's sample size determination formula: (I.e. $=\mathrm{N} / 1+\mathrm{N}(\mathrm{e}) 2$. The study divulged that the EFL students have negative perception towards learning reading using communicative language teaching approach. As a result, student's negative perception towards learning reading skill using communicative language teaching approach was found. Hence, based on the findings, recommendations were made. In concurrence to this, the researchers recommend that the concerned bodies should give due attention to overcome selected problems which hampers learning reading skills using communicative language teaching approach particularly mobilizing EFL teachers and students through continuous capacity building activity is paramount.
\end{abstract}

Keywords: Perceptions, Challenges, Reading Skills and CLT

\section{Introduction}

According to Borg [1] teacher's and student's perceptions regarding reading instruction through communicative language teaching is one of the most influential factor on what is done in classrooms and in the end on what students learn. There is now agreement in general in language academia that teaching is a cognitive activity in which teachers' perceptions greatly impact their instructional decisions in the classroom Harmer, [2]; Richards and Rodgers, [3]. Within second language education, teaching reading is also viewed as a complex cognitive activity Borg [1]. The same author advocates that teachers are active and thinking decision-makers who make instructional choices by drawing on complex practicallyoriented, personalized, and context-sensitive networks of knowledge, thoughts, and beliefs Borg [1]. Irrefutably, research has indicated that teachers have a vast collection of complex beliefs about pedagogical issues including perception about teachers' and students' thought processes and classroom practices Blair \& Williams, [4]; Borg, [1]; Richards and Rodgers, [3].

These beliefs are whispered to form a structured set of principles and are derived from a teacher's prior experiences, school practices, and a teacher's individual perceptions Borg, [1]. Furthermore, Barkley [5] suggested that what teachers do in the classroom is governed by what they perceive to work best and these perceptions often serve to act as filters through which instructional judgments and decisions are made. Borg [1], Senechal \& LeFevre [6], Francis [7], Richards and Rodgers, [3] point out that there is need to understand; and give account for the underlying belief systems of language teachers while teaching reading through CLT and the impact of these have on their classroom practices in order to improve instructive practices. 


\section{Problem Identified}

According to Ellis [8] \& Greenwood [9], especially English as Second and Foreign Language learners, confront a variety of difficulties while reading. These difficulties comprise in adequate vocabulary, lexical inefficiency, structural complexity, language in accessibility, poor reading skills, lack of schemata, and soon. Students' lack of interest is another major cause of their failure in reading. Reading is, from any of them, "is a passive, boring activity, performed constantly in isolation and perhaps associated with skills which they feel they do not possess "Greenwood, [9]. Dechant [10] expressed the same opinion and stated that achievement in reading is dependent'" up on the learner's motivational readiness, and poor reading or reading failure may be caused by lack of interest. "He also mentioned ' personal maladjustment' as another cause of reading failure and explained that difficulties in adjusting to a new environment, poor parent-child relationships, lack of encouragement from home, 'negative attitudes of parents to learning in general' etc. may all lead to failure in reading.

Concurrence to this, some researchers point out that teachers have some problems in implementing CLT in ESL reading contexts such as teachers problems with the size of the classes as these classes are not large enough to implement reading by means of CLT, and most of the teachers are eager to take form based and knowledge based examinations which conflicts with the principals of CLT Anderson, [11]; Li, [12]; Little wood, [13]; Liao, [14]. Cohen and Teller [15] pointed out that perception of the teachers and students can play a very important role in their implementation of an approach, so teachers' and students' perception regarding the implementation of teaching reading via CLT can affect their practice too. Alemu [16] investigated the importance of implementation of CLT by the teachers on the students interest in language learning in the context of Ethiopia, at the end of the research he came up with the conclusion that teachers' classroom practices in CLT can affect student's performance to a high extent; results of this study reflected this point that Ethiopian students are eager to do form based activities rather than communicative ones.

In understanding the language teacher by studying teachers' perception about reading instruction, Barkhuizen [17] \& Macaro [18], reveal the knowledge that reading cannot be regarded as a set of perfunctory skills to be learnt. They point out that reading is a complex process of making meaning from a text for a variety of purposes and in a wide range of contexts. To a large extent in Ethiopia, reading in English is essential for learners' academic success because English is the medium of instructional formal settings put aside the other languages. However, in many situations where English is learnt as a second language (L2), learners usually experience the lack of reading strategies which are essential for them to read competently and overcome the challenges in the classroom when dealing reading within communicatively designed exercises, Pressley, [19]; Pressley,
El-Dinary, Gaskins, Schuder, Bergman, Almasi, \& Brown, [20].

Communicative language teaching approach was introduced as a main language teaching approach in our country Ethiopia before two decades. Conversely, the reading skill of our high school students is not as expected at their level. For example; sometimes students fail to use basic words for communication and even they cannot express themselves clearly because of lack of reading proficiency.

\section{Objectives of the Study}

\subsection{General Objective}

The general objective of the study is to explore Students' Perceptions related Challenges in Learning Reading Skill using Communicative Language Teaching Approach.

\subsection{Specific Objectives}

Specifically, this study was intended to achieve the following objective:

To explain students' perceptions related challenges of learning reading skills using CLT in Wolaita Sodo Preparatory School.

\section{Research Design and Methodology}

\subsection{Research Design}

It is said that research design is selected based on the purpose and nature of the research. The purpose of this study is identifying student's allied challenges in learning reading skill using communicative language teaching approach. To achieve the purpose of this study, descriptive survey design was employed and that includes both quantitative and qualitative techniques of data analysis.

\subsection{Research Setting}

This study was conducted at Wolaita Sodo Preparatory School. It is located about $315 \mathrm{Km}$ away from Addis Ababa via Alaba direction. The

Major reason why the researchers selected this school to conduct their study is that the researchers observed that the extent to which communicative language teaching approach was used to teach reading was not yet studied.

\subsection{Participants of the Study}

In this study, students of grade ten were selected. There are 838 students in the selected school. Among of them, 270 students were involved in this study.

\subsection{Sampling Techniques}

There are 838 students in the selected school; among 838 students, the researchers were selected the sample using Slovene's sample size determination formula: (I.e. $=\mathrm{N} / 1+\mathrm{N}(\mathrm{e}) 2 \mathrm{~N}=$ total population, Where: $\mathrm{n}=$ is sample 
size $(\mathrm{e})=0.05$ or allowance of random error. $838 \times 0.0025=2.095+1=3.095=838 / 3.095=270$ Therefore, 270 students were selected for filling the questionnaire. Both total teachers and their students were observed during teaching and learning process of reading lessons via communicative language teaching approach.

\subsection{Tools of Data Collection}

To collect valuable and relevant data, two important instruments of data collection were employed. These are questionnaire and non-participant observation. These tools were developed primarily to meet the objectives of the study.

\subsubsection{Questionnaire}

The main purpose of the questionnaire is to explore student's perceptions related challenges in learning reading using CLT at Wolaita Sodo Preparatory School.

\subsubsection{Classroom Observation}

The classroom observation is important to get direct and practical information rather than self-report accounts Dornyei, [21]. Sarantakos [22] points out that in non-participant observation, the researcher observed onto take part in the classroom teaching learning process and the observer simply observes the existing situation. Hence, among types of observation, non-participant observation was employed to collected at a forth is study.

\subsection{Methods of Data Analysis}

The data which was gathered from students through classroom observation and questionnaires were analyzed, interpreted and discussed. Finally, the qualitative data were analyzed thematically. Based on the results, conclusions and recommendations were made.

\section{Discussions and Results}

To achieve objectives of the study, data was gathered from students of Wolaita Sodo Preparatory school via questionnaire and classroom observation. The data assembled through the close-ended items of the questionnaire and classroom observation was analyzed quantitatively. While the data gathered through open ended questionnaire was analyzed qualitatively or verbatim.

Students Perception Related Challenges in Learning Reading Using CLT

A. Students Questionnaires Response on items related to students perception's related challenges in learning reading skills using CLT.

EFL students of the school asked to complete questionnaire whether they positively or negatively perceived when learning reading using communicative language teaching approach or not. With regard to this, 270 selected students completed the questionnaire below the table.

Table 1. Students' response on items related to students perception's related challenges in learning reading skills using CLT.

\begin{tabular}{|c|c|c|c|c|c|c|c|c|c|c|c|c|c|}
\hline \multirow{3}{*}{ No } & \multirow{3}{*}{ Items } & \multicolumn{12}{|c|}{ Responses } \\
\hline & & \multicolumn{2}{|l|}{ SD } & \multicolumn{2}{|l|}{ D } & \multicolumn{2}{|c|}{ UD } & \multicolumn{2}{|l|}{$\mathbf{A}$} & \multicolumn{2}{|l|}{ SA } & \multirow{2}{*}{$\begin{array}{l}\text { Total } \\
\text { F }\end{array}$} & \multirow{2}{*}{$\begin{array}{l}\text { Mean } \\
\% \\
\end{array}$} \\
\hline & & $\overline{\mathbf{F}}$ & $\%$ & $\mathbf{F}$ & $\%$ & $\mathbf{F}$ & $\%$ & $\mathbf{F}$ & $\%$ & $\mathbf{F}$ & $\%$ & & \\
\hline 1 & Bottom up approach promote my reading skills & 60 & 22 & 40 & 14 & 50 & 18 & 70 & 25 & 50 & 18 & 270 & 100 \\
\hline 2 & Different interactive activities promote my reading skills & 20 & 7 & 120 & 44 & 30 & 11 & 50 & 18 & 50 & 18 & 270 & 100 \\
\hline 3 & Reference questions promote my reading skills & 35 & 13 & 62 & 23 & - & - & 105 & 39 & 67 & 25 & 270 & 100 \\
\hline 4 & Basal reader (whole language) approach promote my reading skills & 103 & 38 & 55 & 20 & 58 & 21 & 53 & 20 & 59 & 22 & 270 & 100 \\
\hline 5 & Literature based approach promote my reading skills & 90 & 34 & 50 & 19 & - & - & 70 & 25 & 60 & 22 & 270 & 100 \\
\hline 7 & Task based approach promote my reading skills & 96 & 36 & 64 & 24 & - & & 58 & 22 & 52 & 19 & 270 & 100 \\
\hline 8 & Content based approach promote my reading skills & 98 & 35 & 72 & 27 & - & - & 50 & 19 & 50 & 19 & 270 & 100 \\
\hline 9 & Cooperative language learning approach promote my reading skills & 32 & 12 & 58 & 21 & - & - & 150 & 56 & 30 & 12 & 270 & 100 \\
\hline
\end{tabular}

Key: $\mathrm{SD}=$ StronglyDisagree, $\mathrm{D}=$ Disagree, $\mathrm{UD}=$ Undecided, $\mathrm{A}=$ Agree and $\mathrm{SA}=$ Strongly Agree.

As depicted table 1item, $25 \%$ of EFL students of the School agreed with bottom up approach promote their reading skills when they were learning reading skills using communicative language teaching approach. Besides, $18 \%$ of respondents strongly agreed up on bottom up approach promote their own reading skills. Therefore, the result of respondents' questionnaire disclosed that $43 \%$ agreed up on bottom up approach promote their reading skills including strongly agree and agree score points. Henceforth, majority of the EFL students of the school have positive attitude towards bottom up approach to learn reading skills through communicative language teaching approach.

As displayed table 1 item 2, 45\% of EFL students disagreed with different interactive activities promote their reading skills when they were learning reading using communicative language teaching approach. This implies that $45 \%$ of students of the school disagreed with different interactive activities promote when they were learning reading skills through communicative language teaching approach. Accordingly, $45 \%$ of EFL teachers were negatively conceived that different interactive activities promote their reading skills using communicative language teaching approach.

As depicted in the above table 1 item $3,39 \%$ of the EFL students of the School agreed up on reference questions promote their reading skills when they were learning reading skills using communicative language teaching approach. This implies that majority of the students positively conceived that reference questions promote their reading skills when they were learning reading using communicative language 
teaching approach. Henceforth, reference questions can promote students reading skills when they were learning communicative language teaching approach.

As displayed table 1 item $4,38 \%$ of the EFL students of the School strongly disagreed up on basal reader (whole language) approach promote their reading skills when they were learning reading skills using communicative language teaching approach. This data displays that majority of the EFL students of the school negatively perceived basal reader or whole language approach promotes their reading skills when they were learning reading using communicative language teaching approach. Therefore, $38 \%$ of EFL students of the school negatively conceived whether or not basal reader or whole language approach when they were learning reading using communicative language teaching approach.

As depicted in table 1 item5, 34\% of EFL students of the school responded that they were strongly disagreed that the literature based approach promote their reading skills when they were learning reading using communicative language teaching approach. Therefore, the questionnaire data disclosed that $34 \%$ of EFL students were strongly disagreed when they were learning reading using communicative language teaching approach.

As displayed table 1 item $6,44 \%$ of EFL students of the School students were strongly agreed with language experience approach promote their reading skills when they were learning reading using communicative language teaching approach. This infers that $44 \%$ of EFL students were positively conceived that language experience approach promote their reading skills when they were learning reading skills using communicative language teaching approach.

As depicted table 1 item 7, 36\% of the EFL students were responded that they were strongly disagreed that task based approach promote reading skills when they were learning reading skills using communicative language teaching approach. This infers that $36 \%$ of EFL students were negatively conceived whether task based approach promote reading skills when they were learning reading skills using communicative language teaching approach.

As displayed table 1 item $8,35 \%$ of EFL students were reported that they were strongly disagreed that content based approach promote their reading skills when they were learning reading using communicative language teaching approach. This implies that majority of EFL students strongly disagreed that content based approach promotes their reading skills when they were learning reading skills using communicative language teaching approach.

As depicted table 1 item 9, 56\% of EFL students responded that they were strongly agreed up on cooperative language learning approach promote their reading skills using communicative language teaching approach. The result of the questionnaire data disclosed that cooperative language learning approach promotes students when learning reading using communicative language teaching approach.

In deduction to A, students' questionnaires response on items related to students perception's related challenges in learning reading skills using CLT: majority of EFL students negatively perceived on strategies of learning or teaching reading using communicative language teaching approach. This implies that most of them not sure that whether or not different approaches of learning reading using communicative language teaching approach promotes their learning of reading in CLT. Therefore, majority of them have negative attitude towards approaches of teaching reading using communicative language teaching approach. This is because of lack of knowledge about learning strategies of reading skills, lack of awareness, lack of skill, and lack of experience how reading taught through communicative language teaching approach.

B. The Result of Classroom Observation on What kind of challenges both EFL Teachers and Students face when teaching and learning Reading using CLT.

Four reading skill lessons were observed for three times and totally the twelve reading lessons were observed what kind of challenges both teachers and students face when teaching and learning reading using CLT. In rejoinder to this each items were analyzed below:

The twelve reading teaching lessons were observed to see whether or not the English teachers afford bottom up approach when teaching reading skills. With regard to this, T1 and T3 afforded bottom up approach when teaching reading using different strategies such as reminding them meaning of each words, phrases and sentences. Further, T2 afforded when teaching reading using simply calling letters and symbols. Besides, T4 afforded bottom up approach using key words then defining them and giving activities how his students refer and infer activities which is taken from reading passage. This data obtained from classroom observation reveals that majority of teachers afford bottom up approach when teaching reading. Therefore, EFL teachers of the school afforded bottom up approach to teach reading skills.

With regard to item second, T3 provided top down approach when teaching reading skills using varieties of tasks. On the other hand, T1, T2 and T4 were not observed when teaching reading skills providing top down approach. This implies that majority of teachers have gap in providing top down approach when teaching reading using communicative language teaching approach. Hence, the classroom data revealed that most EFL teachers of the school gave less attention for top down approach when teaching reading skills. In item 3, EFL teachers were observed to see whether or not they use inference when teaching reading skills. In retort to this, among the twelve reading lessons none of reading lessons were observed when they used inferences in teaching reading skills. The classroom data disclosed that most of EFL teachers of the school did not used inferences when they were teaching reading skills.

In item 4, reading skills lessons were observed whether or not EFL teachers activate prior knowledge when teaching reading skills. With regard to this, almost all teachers of the school activated prior knowledge of their students when teaching reading skills. The result of the classroom data revealed that almost all teachers activate their students' prior knowledge when teaching reading skills. In item 5, twelve 
reading skill lessons were observed whether or not EFL teachers use reference questions when teaching reading. With regard to this, almost all EFL teachers of the school used reference questions when they were teaching reading. This implies that almost EFL teachers were using reference questions while teaching reading.

Again then in item 6, EFL reading lessons were observed whether or not teachers provide varieties of interactive activities when teaching reading. In riposte to this, none of the EFL reading lessons were observed when the EFL teachers were providing varieties of interactive activities when teaching reading make use of communicative language teaching approach. Henceforth, the classroom observation data disclosed that most of the EFL teachers were not providing varieties of interactive activities while teaching reading skills this is because of the lesson plan is not suits for teaching reading using varieties of interactive activities.

Concerning item7, the EFL reading lessons were observed to see whether or not teachers of the School convey the interactive approach when teaching reading skills. With regard to this, none of the EFL reading skills lessons were observed when they were conveying interactive approach teaching reading skills. Therefore, almost all EFL teachers of the school did not conveyed interactive approach when teaching reading skills.

In item8, T1 used task based instructions when teaching reading skills. He delivered different task based instructions such as varieties of tasks when he was teaching reading skills. In contrary to this, majority of EFL teachers of the School were didn't use task based instruction when they were teaching reading skills. The result of classroom observation disclosed that almost all EFL reading lessons were not observed when they were using task based instructions in teaching reading skills. This infers that most of the EFL teachers were not used task based instructions when they were teaching reading skills.

In item 9, reading lessons were observed whether or not EFL teachers use content based instructions when teaching reading skills using communicative language teaching approach. In rejoinder to this, most of the EFL lessons were not observed when they were using content based instructions to teach reading skills. Henceforth, the classroom observation result unveiled that most of the EFL teachers did not use content based instruction when teaching reading skills using communicative language teaching approach.

In item 10, EFL reading lessons were observed to see whether or not teachers deliver cooperative language learning approach to teach reading using communicative language teaching approach. In retort to this, $\mathrm{T} 1$ and $\mathrm{T} 2$ assigned students in group and giving different activities which is taken from the reading text. Whileas, T3 and T4 were not observed when they were teaching reading skills using communicative language teaching approach. Therefore, the result of the classroom observation revealed that half of EFL teachers of the school delivered cooperative language teaching approach when teaching reading skills using communicative language teaching approach.
In item 11, EFL reading lessons were observed to see whether or not the class size suitable for teaching reading using communicative language teaching approach. With regard to this, the researchers observed that class size is not suitable for teaching reading using communicative language teaching approach. Therefore, the class size of the school not suitable for teaching reading using communicative language teaching approach. This implies that all of the observed classes are overcrowded and the class is said to be large. The result of the observation disclosed that the class size is not suitable to teach reading make use of communicative language teaching approach in Wolaita, Sodo Preparatory School context.

With regard to item 12, EFL reading lessons were observed to see whether or not teachers use authentic materials when teaching reading. In riposte to this, none of the reading lessons observed when EFL teachers were using authentic materials when teaching reading using communicative language teaching approach. This implies that all of the EFL teachers of the school used authentic materials when teaching reading using communicative language teaching approach. Thus, the result divulged that all of the EFL teachers of the school didn't use authentic materials when they were teaching reading skills.

In item 13, the researchers were observed the existing challenges of teaching reading using communicative language teaching approach. The observed challenges are: lack of knowing strategies of teaching reading using CLT, lack of prior knowledge, lack of experience in teaching reading using CLT, lack of enough space between chairs, tables and desks, lack of enough sitting materials, lack of textbook, large class size, lack of interest of students, loss of confidence, language anxiety and teaching method itself.

\section{Summary, Conclusions and Recommendations}

Based on the analyses of the collected data, the following summary, conclusions, and recommendations were made. Hence, these parts intended to enlist the summary of the major findings, conclusion and recommendation.

\subsection{Summary of the Major Findings}

Different findings were obtained from the analysis of data. The findings of the study were organized and grouped according to the objective of the study. Thus, in this subsection, the summary of the major findings is presented according to the objective of the study.

Students' Perception's related Challenges on learning reading skills using communicative language teaching approach.

The study divulged that the students' questionnaires response on items related to students perception's related challenges in learning reading skills using CLT: majority of EFL students negatively perceived on strategies of learning or teaching reading using communicative language teaching 
approach. This implies that most of them not sure that whether or not different approaches of learning reading using communicative language teaching approach promotes their learning of reading in CLT. Therefore, majority of them have negative attitude towards approaches of teaching reading using communicative language teaching approach. This is because of lack of knowledge about learning strategies of reading skills, lack of awareness, lack of skill, and lack of experience how reading taught through communicative language teaching approach.

\subsection{Conclusions}

Based on the analysis of data in the previous sections, the researchers came up with the following conclusions.

Students' questionnaires response on items related to students perception's related challenges in learning reading skills using CLT: majority of EFL students negatively perceived on strategies of learning or teaching reading using communicative language teaching approach. This implies that most of them not sure that whether or not different approaches of learning reading using communicative language teaching approach promotes their learning of reading in CLT. Therefore, majority of them have negative attitude towards approaches of teaching reading using communicative language teaching approach. This is because of lack of knowledge about learning strategies of reading skills, lack of awareness, lack of skill, and lack of experience how reading taught through communicative language teaching approach.

The classroom observation results showed that student's perception related challenges in learning reading using CLT, there are observed challenges which impede students while teaching reading using communicative language teaching approach. For example, students' ability of learning reading using CLT into classroom context, interest related perception, shortage of textbook, lack of interest, large class size, shortage of sitting materials, shortage background knowledge, lack of practice, lack of motivation, negative attitude towards interactive activities, poor in comprehension skills, lack of contextualizing meanings, shortage of vocabularies, lack of grammar, lack of collaborative tasks and interactional nature of learning, lack of confidence, lack of awareness and less attention.

\subsection{Recommendations}

Based on the findings obtained and conclusion made, the following recommendations are forwarded: As divulged in the findings, the respondents listed different factors that affect teaching and learning reading using communicative language teaching approach. Hence, the concerned bodies should fulfill the school setting related challenges that can affect the teaching of reading skills using the communicative language teaching approach, and the student and teacher related factors should mitigate through well-built mobilization.

\section{References}

[1] Borg, S. (2003). Teacher Cognition in Language Teaching: A review of research on what Language teachers think, know, believe, and do. Journal of ELT, 36, (5), 81-109.

[2] Harmer, J. (2001). The practice of English language teaching. New York: Long man Press.

[3] Richards, J. C. \& Rodgers, T. S. (2001). Approaches and Methods in language teaching Second Edition. New York, NY: Cambridge University Press.

[4] Blair Larsen, SM and Williams, KA. (2004). The Balanced Reading Program, USA: International Reading Association.

[5] Barkley, J. M. (2006). Reading education: is self efficacy important? Reading improvement, 43 (4) 194-210.

[6] Senechal, M. \& LeFevre, J. A. (2002). Parent Involvement in the Development of Children's Reading Skills: A five-year longitudinal study. Child Development. 73 (2) 445-460.

[7] Francis, L. (2000). Reading problem: Define (online) http:// www.cco.net/ $\sim$ reading problems/ definitions. Html.

[8] Ellis, R. (2002). The Study of Second Language Acquisition. Auckland: Oxford University Press.

[9] Green wood, J. (1998). Class Readers. Hongkong: Oxford University Press.

[10] Dechant E. V. (1982). Improving the Teaching of Reading. New Jersey: Prentice- Hall, Inc.

[11] Anderson, J. (1993). "Isa Communicative Approach Practical for Teaching English in China? Pros and Cons." System 21 (4), p 471-480.

[12] Li, D. (1998). It's always more difficult than you plan and imagine: Teachers' perceived difficulties in introducing the communicative approach in South Korea. TESOL Quarterly. 32, 677-703.

[13] Little wood, W. (2007). Communicative and task based language teaching in East Asian classrooms.

[14] Liao, X. (2003). The need for Communicative Language Teaching in China. ELT Journal. 58, 270273. Language Teaching, 40, p 243-249.

[15] Cohen, M. D., \& Teller, K. (1994) Implementing cooperative learning for language minority students. Bilingual Research Journal, 18, (1), 19.

[16] Alemu, H. (2004). An Evaluative Study of ELT Practice in Secondary Schools in Ethiopia: 2004 (Unpublished PhD dissertation). Hyderabad: Central Institute of English and Foreign Language.

[17] Barkhuizen, G. P. (1998). Discovering learners' perceptions of ESL classroom teaching/ learning activities in a South African context. TESOL Quarterly, 32 (1), 85-108.

[18] Macaro, E. (2006). Strategies for language learning and for language use: Revising the theoretical framework. The Modern Language Journal 90. 3,320-337.

[19] Pressley, M. (2006). Reading instruction that works: The case for balanced teaching (3rded.). New York: Guilford. 
[20] Pressley, M., El-Dinary, P. B. Gaskins, I., Schuder, T. Bergman, J., Almasi, J., \& Brown, R. (1992). Beyond direct explanation: Transactional instruction of reading comprehension strategies. Elementary School Journal, 92, 513-555.
[21] Dorneyi, Z. (2007). Research Methods in Applied Linguistics. Oxford: Oxford U: Press.

[22] Sarantakos, S. (2005). Social Research (Third edition). New York: Palgrave Mc Millen. 